5 Garcia $M$, Miller M, Moses AM. Chlorpropamide-induced water retention in patients with diabetes mellitus. Ann Intern Med 1971;75:549-55.

(Accepted 8 October 1984)

Endocrinology Research Group, Northwick Park Hospital and Medical Research Council Clinical Research Centre, Harrow, Middlesex HA1 3U J

R EASTELL, MB, MRCP, registrar in endocrinology

C J EDMONDS, DSC, FRCP, consultant physician

Correspondence and requests for reprints to: Dr C J Edmonds.

\section{Abnormalities of cardiac conduction in diabetics}

The Framingham study showed that death from heart failure in diabetes exceeded that predicted by atherogenic risk factors. Subsequently several workers using echocardiographic or systolic time interval techniques found evidence of subtle defects in myocardial performance in diabetics. ${ }^{1}$ Excess fibrosis and capillary microaneurysms have been noted in the human diabetic heart, but no correlation has been found between histopathological findings and specific cardiac abnormalities. ${ }^{2}$ In a study of 100 patients with idiopathic chronic heart block, however, the prevalence of overt diabetes mellitus was $9 \%$, which was well in excess of the prevalence in a group of hospital inpatients of comparable age. ${ }^{3}$ We attempted to ascertain whether the His-Purkinje system is vulnerable to such a microangiopathic process by comparing the frequency prevalences of conduction disturbances, using standard 12 lead electrocardiography, in diabetics and patients with hypertension.

\section{Patients, methods, and results}

We selected consecutively from the diabetic clinic a heterogenous group of 200 patients with established type I or Type II diabetes but excluded patients with a history of infarction or angina pectoris and those taking drugs known to interfere with cardiac conduction. Standard 12 lead electrocardiography was carried out on patients in the supine position after a rest period of five minutes. Electrocardiography was similarly carried out on 200 patients with hypertension matched for age. All hypertensive patients had severe disease requiring at least triple treatment in the form of a $\beta$ blocker, vasodilator, and thiazide diuretic. None had clinical diabetes. Electrocardiograms were scrutinised, and the heart rate and prevalences of atrioventricular block and right and left bundle branch block were documented according to the criteria of the Minnesota code (table). Results were analysed with the $\chi^{2}$ test.

The diabetics had a significantly higher prevalence of both first degree atrioventricular and right bundle branch block compared with the patients

Characteristics of patients with hypertension and diabetes and prevalence of electrocardiographic conduction abnormalities

\begin{tabular}{|c|c|c|c|}
\hline & Diabetics & $\begin{array}{l}\text { Patients with } \\
\text { hypertension }\end{array}$ & p Value \\
\hline $\begin{array}{l}\text { No of patients } \\
\text { Male :female } \\
\text { Mean (range) age (years) }\end{array}$ & $\begin{array}{c}200 \\
108: 92 \\
47 \\
(19-65)\end{array}$ & $\begin{array}{c}200 \\
104: 96 \\
48 \\
(19-65)\end{array}$ & NS \\
\hline $\begin{array}{l}\text { No in age range: } \\
19-35 \\
36-50 \\
51-65\end{array}$ & $\begin{array}{l}64 \\
64 \\
72\end{array}$ & $\begin{array}{l}67 \\
65 \\
68\end{array}$ & \\
\hline $\begin{array}{l}\text { Mean (range) heart rate } \\
\text { (beats/min) }\end{array}$ & $\begin{array}{c}80 \cdot 1 \\
(47-112)\end{array}$ & $\begin{array}{c}83 \cdot 7 \\
(52-116)\end{array}$ & NS \\
\hline $\begin{array}{l}\text { No with first degree } \\
\text { atrioventricular block* } \\
\text { No in age range: }\end{array}$ & 14 & 4 & $0.02\left(\chi^{2}=5.82\right)$ \\
\hline $\begin{array}{l}\text { No in age range: } \\
19-35 \\
36-50 \\
51-65\end{array}$ & $\begin{array}{l}2 \\
5 \\
7\end{array}$ & $\begin{array}{l}1 \\
1 \\
2\end{array}$ & $\begin{array}{l}\text { NS } \\
\text { NS } \\
\text { NS }\end{array}$ \\
\hline $\begin{array}{l}\text { No with right bundle branch } \\
\text { blockt } \\
\text { No in age range: }\end{array}$ & 13 & 4 & $<0.05\left(\chi^{2}=4.98\right)$ \\
\hline $\begin{array}{l}19-35 \\
36-50 \\
51-65\end{array}$ & $\begin{array}{l}4 \\
4 \\
5\end{array}$ & $\begin{array}{l}1 \\
1 \\
2\end{array}$ & $\begin{array}{l}\text { NS } \\
\text { NS } \\
\text { NS }\end{array}$ \\
\hline $\begin{array}{l}\text { No with left bundle branch } \\
\text { block } \neq \\
\text { No in age range: }\end{array}$ & 4 & 10 & NS \\
\hline $\begin{array}{l}19-35 \\
36-50 \\
51-65\end{array}$ & 4 & $\begin{array}{l}2 \\
4 \\
4\end{array}$ & $\begin{array}{l}\text { NS } \\
\text { NS } \\
\text { NS }\end{array}$ \\
\hline
\end{tabular}

*PR interval $\geqslant 0.22 \mathrm{~s}$

$T Q R S \geqslant 0.12 \mathrm{~s}$ with $\mathrm{R}$ prime $>R^{1}$ in lead VI

$\ddagger Q R S \geqslant 0.12 \mathrm{~s}$ with $\mathrm{R}$ peak duration $\geqslant 0.06 \mathrm{~s}$ in any of leads $\mathrm{I}, \mathrm{II}, \mathrm{L}, \mathrm{V} 5$, or V6. with hypertension. Left bundle branch block was more common in the hypertensive patients, but the difference was not significant. Stratifying the two populations into three groups on the basis of age showed a trend of increasing prevalence of all three conduction disturbances with age. In all three age groups, however, first degree atrioventricular and right bundle branch block were at least twice as common in the diabetics as in the patients with hypertension.

\section{Comment}

Although the association between left bundle branch block and hypertension is well recognised and thought to reflect to some degree the severity of left ventricular hypertrophy and arteriosclerotic heart disease, the aetiology of most conduction disturbances remains obscure. Chronic acquired complete heart block is commonly preceded by various conduction abnormalities and is often the end stage of a chronic and progressive disease destroying the conduction system. ${ }^{4}$ Atherosclerosis of the major coronary arteries is not responsible. Hasslacher and Wahl found a prevalence of diabetes mellitus of $41 \%$ among 473 patients permanently paced for bradyarrhythmias. ${ }^{5}$

The compact anatomical nature of the right bundle branch and atrioventricular node when compared with the more diffuse left bundle branch may increase their vulnerability to the patchy fibrotic process seen in the diabetic myocardium. We believe that the higher prevalence of both first degree atrioventricular and right bundle branch block in diabetics is related to microangiopathic rather than arteriosclerotic disease. Such findings give further support to the role of diabetes mellitus in the pathogenesis of complete heart block in some cases.

We thank Professor J D Swales for permission to study the electrocardiographic records from the hypertension clinic, and Mrs N Sharma for typing the manuscript.

1 Shapiro LM, Howat AP, Calter MM. Left ventricular function in diabetes mellitus. Br Heart $\mathcal{f} 1981 ; 45: 122-8$.

Ledet T. Diabetic cardiopathy: quantitative histological studies of the heart from young juvenile diabetics. Acta Pathologica et Microbiologica Scandinavica

Fairfax AJ, Leatham A. Idiopathic heart block: association with vitiligo, thyroid disease, pernicious anaemia and diabetes mellitus. $\mathrm{Br}$ Med $\mathcal{F} 1975$;iv:322-4.

Kulbertus HE, Demoulin JC. The conduction system: anatomical and pathologica aspects. In: Krikler DM, Goodwin JF, eds. Cardiac arrhythmias: the modern electrophysiological approach. London: WB Saunders, 1975:16-38.

5 Hasslacher C, Wahl P. Diabetes prevalence in patients with bradycardiac arrhythmias. Acta Diabetol Lat 1977;14:229-34.

(Accepted 2 October 1984)

Department of Medicine, Leicester General Hospital, Leicester LE5 4PW

R L BLANDFORD, MD, MRCP, senior registrar

A C BURDEN, MD, MRCP, consultant

Correspondence to: Dr R L Blandford.

\section{Nasal obstruction in healthy neonates}

Most newborn infants have to breathe through their noses. Any obstruction in the nose or nasopharynx may cause difficulty in breathing and feeding. We present two cases of nasal obstruction causing respiratory problems in neonates who had normal airways severely congested by nasal mucosa.

\section{Case reports}

Case 1-An 18 hour old girl was referred with cyanotic episodes and obstructed nasal breathing. A 6 French gauge catheter was passed with some difficulty into the oropharynx via both nasal cavities. Findings on radiology, microlaryngoscopy, and bronchoscopy were normal. Examination of the nose and postnasal space showed no abnormality apart from severe mucosal congestion, and the nasal airways were easily dilated from 6 to 12 French gauge. Because of persistent difficulty in nasal breathing after this procedure a $3 \mathrm{~mm}$ nasopharyngeal airway was inserted. If this was removed obstructed nasal breathing resumed. Nasal stents were therefore inserted under general anaesthesia but were blocked with inspissated nasal secretions within two days despite regular passage of suction catheters and were removed. A $3.5 \mathrm{~mm}$ nasopharyngeal airway $7 \mathrm{~cm}$ long was placed in the right nostril. The child managed with this and was sent home with the airway in place. The airway was removed six weeks later, by which time she could breathe through her mouth. Three months later she was healthy, breathing easily through nose and mouth, and feeding well. 